Article

\title{
Reaching Sustainable Financial Health: Gender Differences in Risk-Taking Patterns of Financially Excluded People
}

\author{
Eunmi Kim ${ }^{1}$, Sejoong Lee ${ }^{2, *(\mathbb{D})}$ and Joonwhan David Lee ${ }^{2}$ \\ 1 Department of Economics, Ewha Womans University, 52 Ewhayeodae-gil, Seodaemun-gu, \\ Seoul 03760, Korea; lovelygomgom@ewhain.net \\ 2 College of Business Administration, Hongik University, 94 Wausan-ro, Mapogu, Seoul 04066, Korea; \\ jdfresh@hongik.ac.kr \\ * Correspondence: lee0819@hongik.ac.kr; Tel.: +82-2-320-1761
}

Received: 23 March 2018; Accepted: 19 April 2018; Published: 22 April 2018

\begin{abstract}
Providing sufficient financial accessibility to low-income individuals is considered a way to decrease income inequality and could be a key factor in sustainable economic growth. To make the financial accessibility policy more effective, analyses of individuals' understanding of financial risk within low-income groups need to be conducted. The current authors investigated individuals' attitudes towards loan financial risk in terms of gender difference. Using South Korean survey data, we examined the relationship between gender and attitude towards loan financial risk with a regression analysis. We found that within a low-income group, males were more willing to pay higher interest rates than females. In addition, males' willingness to pay high interest rates became stronger when their current financial costs were high. The results indicate that males are less careful with the risks that high interest rates can bring. Thus, the results imply that interventions, such as more substantial financial education, are required for males to make financial accessibility polices more effective.
\end{abstract}

Keywords: sustainable growth; financial accessibility; gender difference; risk attitude

\section{Introduction}

Achieving sustainable economic growth has been actively discussed since the 2007 global financial crisis. International organizations, such as the Organization for Economic Co-operation and Development (OECD) and International Monetary Fund (IMF), are interested in this subject and have reported that a decrease in income inequality may be a key factor for sustainable economic growth [1,2]. The study theoretically summarizes the adverse effects of inequality on the sustainability of economic growth in several aspects [1]. Inequality may decrease economic growth because it can cause political and social instability, and it may obstruct human capital accumulation within low-income populations. In addition, if inequality restricts domestic demand expansion, it may restrain technological innovation. Thus, finding effective ways to decrease income inequality is a crucial task for sustainable economic growth. The provision of sufficient financial accessibility to low-income individuals has been recently considered as one of the ways to achieve this goal. However, to prepare a more effective financial accessibility policy for low-income individuals, an analysis of the differences in individuals' understanding about financial risk within low-income groups needs to be preceded. If financial risk is less recognized in individuals with certain characteristics, a financial accessibility policy may have heterogeneous effects within the low-income group, weakening its effectiveness. Thus, in this paper, we aim to investigate individuals' attitudes to financial risk within 
a low-income group using survey data collected in South Korea. Furthermore, we aim to seek more effective and efficient sustainable strategies for practitioners and related policy makers.

Financial access is defined as the "access by individuals and businesses to different forms of capital and financial services" [3]. In other words, it refers to the degree to which individuals can access financial services, such as savings, loans and insurance. Previous study has shown that high financial accessibility helps individuals to accumulate assets and eventually, assists in preparation of their retirement plan [4]. In addition, researchers have shown that high financial accessibility also mitigates the adverse impacts of economic recession on personal welfare by helping individuals access financial services [4]. Another study investigated the effect of financial service provision to low income-individuals and found that financial service provision increased their income level [5]. International organizations also tend to regard the improvement of financial accessibility as a useful tool for achieving sustainable development. The United Nations emphasize the importance of financial accessibility for the achievement of sustainable development goals by 2030 [6]. The World Bank Group has stated that universal financial access may contribute to poverty reduction [7]. The Korean government has also tried to improve the financial accessibility of low-income groups by providing emergency funds, start-up funds, interest discounts, and mortgage loans, etc.

To make these financial accessibility policies more effective, individuals' understanding of financial risk within low-income group needs to be analyzed. When individuals in low-income groups have a poor understanding of financial risk, they tend to easily accept higher financial costs when making important financial services decisions. Unfortunately, if a subgroup with certain characteristics is less informed of financial risk compared to others, the financial burden of this subgroup may become higher. Thus, escaping from a low-income status may be more difficult in this subgroup compared to others. This phenomenon creates a public policy issue in that it implies a financial accessibility policy may have a heterogeneous effect among low-income groups depending on their understanding of financial risk. Following this rationale, we argue that a financial accessibility policy for low-income groups needs to be accompanied with a microlevel analysis regarding the understanding of financial risk within each group.

Among the variety of factors that may influence the understanding of financial risk in low-income individuals, our study focuses on gender difference for the following reasons: First, previous studies have investigated the difference in financial risk perception between genders [8-11], but investigating whether the results are also applicable to low-income individuals may be meaningful because the economic environment that low-income people confront may dilute the difference. Second, the main interests of numerous prior studies documenting gender differences in financial risk perception have tended to be limited to financial risk-taking behaviors during financial investment [8-11]. Our knowledge about gender difference in borrowing remains rudimentary. Thus, this study presents a novel perspective for the gender difference in risk perception, in that it focuses on the financial costs associated with loans. Third, the financial accessibility policies for low-income groups tend to focus on economic conditions, such as income level and housing status. In fact, policy design does not fully reflect the potential differences in financial risk attitudes between genders. For example, while individuals' credit ratings and income levels are considered in the application for a "Sunshine Loan" in Korea, there is no consideration of gender. Therefore, we expect the analysis of gender difference in low-income groups may contribute to an improvement in the design of relevant public policies.

In this study, we used data from Korean low-income individuals to investigate gender differences in financial risk attitudes. The empirical results showed that within low-income groups, males are more willing to pay higher financial costs than females. This result implies that males in low-income groups tend to underestimate loan financial risks relative to females in the same group. This is consistent with previous studies in which females have been shown to be more careful regarding risk [8-11]. More importantly, we found that males in low-income groups are more willing to pay higher interest when their current financial costs are high. This result implies that males in low-income groups 
may have more difficulty escaping from their low-income status due to consistently bearing a high financial burden.

The contributions of this study are as follows: First, from a practical point of view, this study implies that special care to males in the low-income group, such as more substantial financial education, needs to occur to make the financial accessibility policy more effective. Second, this study contributes to prior literature that documents the difference in recognition of financial risk between genders [8-11]. As attitude towards financial risk within low-income groups has not been a major focus in the literature so far, this paper fills this gap by examining attitudes to financial risk within low-income groups, through Korean survey data, that could be targeted by policies. Third, previous studies have shown that gender effects may vary by country. For instance, the effects of gender diversification in a board on firm performance in Germany and Denmark [12,13] is different from the effects in the US [14]. Thus, this study contributes to international research by reporting Korean evidence.

This paper is organized as follows: we review prior literature and establish hypotheses in Section 2. In Section 3, we present our research methodology. Section 4 shows empirical results. Finally, Section 5 summarizes and concludes the paper.

\section{Literature Review and Hypotheses}

Gender difference has been widely documented in prior literature from a variety of angles. One line of literature has investigated gender differences in decision-making. Using data from 1334 responses to a survey by the Canadian Tourism Commission, a prior study found that male and female customers have different preferences for online information usage and thus, travel website structure may affect the decisions of male and female customers differently [15]. Another study found that boys are more likely to select more a competitive curriculum program that incorporates higher level math and science than girls [16]. The study argues that this difference may affect their career choices. Gender difference in decision-making has also been observed in the professional workplace. In China, female auditors are likely to apply more conservative standards during audit tasks than their male counterparts [17].

Other researchers have examined the gender difference in terms of moral code. A prior study showed that relative to females, males have a higher tendency of deceiving other people for their own benefit [18]. Another study showed that female and older students behave more ethically in various situations [19]. Similar to these studies, another study showed that females tend to apply stricter moral standards when evaluating business practices [20]. Also, if a group is mainly composed of females, individuals in the group tend not to delay their loan payments [21]. Another line of studies has reported that the presence of females on the board positively affects a firm's corporate social responsibility (CSR) rating and performance [22,23].

Males and females may respond differently to certain behaviors or information. Males and females tend to determine the continuous usage of social network services (SNS) based on different factors [24]. Time consumption in commuting may be more harmful to the mental health of females than males because females spend more time on household tasks [25]. The effect of stress on decision-making, such as tournament entry, varies depending on gender [26]. Gender difference is also observed in the persistence of feelings of satisfaction. While satisfying emotions have more permanent effects on boys, dissatisfaction tend to persist among girls [27].

A gender difference that is frequently cited in economics is the gender difference in risk-taking. From a theoretical perspective, the gender difference in risk-taking may occur because males are more likely to follow sensational events and be more overconfident than females $[28,29]$. A previous study showed that female financial advisors pay more attention to possible gains or losses than their male counterparts in the financial investment industry [30]. In addition, the authors of that study also indicated that female advisors are more careful in interpreting financial information. Other studies have documented the gender difference in risk preference [31-33]. They found that females are more risk averse than males and take different strategies in financial decisions [32]. Similarly, a study found 
that single females are more risk averse than single males. In this study, the authors linked the lower wealth of women compared to men with their difference in risk preference [34]. Another study showed that public financing policies entailing a high guarantee ratio may increase males' credit risk [35].

Although these studies provide some evidence of how females' financial decisions are different from the decisions of their male counterparts, our knowledge regarding the gender difference in risk attitude within low-income people remains rudimentary. Focusing on low-income individuals is important because the effect of a financial accessibility policy on low-income individuals may be influenced by their financial risk attitude. In addition, the gender difference regarding risk attitudes towards loans has not been sufficiently reviewed yet. Our study fills this void. If males tend to follow sensational events and be more overconfident than females, we expect that meager economic conditions may not change these innate characteristics. Thus, we firstly hypothesize that males in low-income groups take more financial risks than their female counterparts. Then, based on the anticipation that higher financial stress may simulate males' tendency to seek sensational events, we secondly hypothesize that males are more likely to take risk when under higher financial pressure. By examining these hypotheses, this study is expected to supplement prior studies regarding gender differences in financial risk-taking that have tended to be limited to financial investment. Also, our study may provide useful implications regarding whether males may find it hard to escape from poverty due to their improper risk attitudes.

\section{Methodology}

\subsection{Data}

We collected the raw data from "The survey on the needs and use of financial services of financially excluded people" executed by the Seoul Welfare Foundation in 2014 [36]. The number of the survey participants was 1005 . They were selected by a random sampling method from the 15,000 participants involved in two financial accessibility plans- "Seoul Hope Plus Savings Accounts Program" and "Seoul Dream-narae Savings Accounts Program".

These two financial accessibility plans are designed to support low-income individuals' accumulation of financial assets as well as providing support for their children's education. The "Seoul Hope Plus Savings Accounts Program" supports low-income individuals by providing an additional public contribution to their savings originating from their work income. This public contribution lasts for 3 years. The other plan, "Seoul Dream-narae Savings Accounts Program", helps low-income individuals to accumulate funds for their children's education. As these two plans focus on low-income families, about $20 \%$ of the plans' participants are public aid recipients, and the remaining $80 \%$ are also included in the low-income bracket. The survey incorporates the participants' economic and social conditions, such as income, employment status, residence type, debt size and education level, etc. Refer to the following link for more detailed information about the plans: https:/ / www.welfare.seoul.kr/information/biz_data/view/14223?p_page=1\&s_ searchType $=\& s \_k e y w o r d=\& s \_c a t e g o r y T y p e=\& b o a r d I d=8 \&$ stus $=\& s \_t e x t=$. Although the total number of participants was 1005, we only used data from 515 of these, due to exclusion of those missing required data.

\subsection{Research Design}

We adopted the "the interest rate level that the participant intends to pay (Interestintention)" as our main dependent variable. In the loan market, financial institutions are more likely to provide higher loans to customers who are willing to pay higher interest rates. For example, private loans companies provide high interest loans without checking borrowers' credit conditions. Thus, if an individual does not fully recognize the danger that high interest loans cause and express a willingness to pay interest rates beyond his/her own ability, the individual's credit condition may deteriorate as time passes. Thus, even though public policies help with their credit recovery or asset accumulation in 
the short term, the policies may not be as effective as expected if the individuals are not fully informed of the financial risks of loans. Thus, we captured the individual's loan risk attitude with "the interest rate level that the participant intends to pay (Interestintention)" in the survey data. We tested whether gender has an effect on the intention to pay high interest by establishing the following regression.

\section{Interestintention}

$$
\begin{aligned}
& =b_{0}+b_{1} \text { Gender }+b_{2} \text { Highrateloan }+b_{3} \text { Defaultex } p+b_{4} \text { Loantime } \\
& +b_{5} \text { Age }+b_{6} \text { Family }+b_{7} \text { Nospouse }+b_{8} \text { Education }+b_{9} \text { Financeeducation } \\
& +b_{10} \text { Nopermanentwork }+b_{11} \text { Nowork }+b_{12} \text { Income }+b_{13} \text { Nohouse }+i e_{t}
\end{aligned}
$$

Interestintention denotes the interest rate level that the participant intends to pay to non-bank financial institutions if he/she cannot get a loan from a commercial bank. This is expected to be higher when the participant does not fully understand the financial risk that higher interest payments may bring. Gender is the variable of interest-a value of 1 denotes male gender and 0 denotes female gender. If gender has a relationship with the intention to pay high interest rates and male participants are more likely to pay higher interest rates, the coefficient, gender $\left(b_{1}\right)$, is expected to have a significant positive sign. We included other variables that the survey incorporates that are expected affect the participants' intentions to pay high interest rates. Highrateloan indicates the share of high interest debt in the total debt. We included this variable because the current financial costs of an individual may be high if they are willing to bear high interest rates. Defaultexp denotes the participants' default experience which may change their financial risk attitude. Loantime is the time taken by participants to search for loan information, implying their prudence about loans.

We controlled for other demographical and social characteristics which may influence the participants' risk attitudes. We selected the variables from the survey data that were well matched to previous studies. In accordance with previous studies that have related demographical properties to risk perception, we controlled for age (Age), dependent families (Family), marital status (Nospouse), education level (Education), employment status (Nopermanentwork, Nowork), income level (Income) and home ownership (Nohouse) [37-40]. We summarize our variable selection processes in Table 1.

Table 1. Variables Selected.

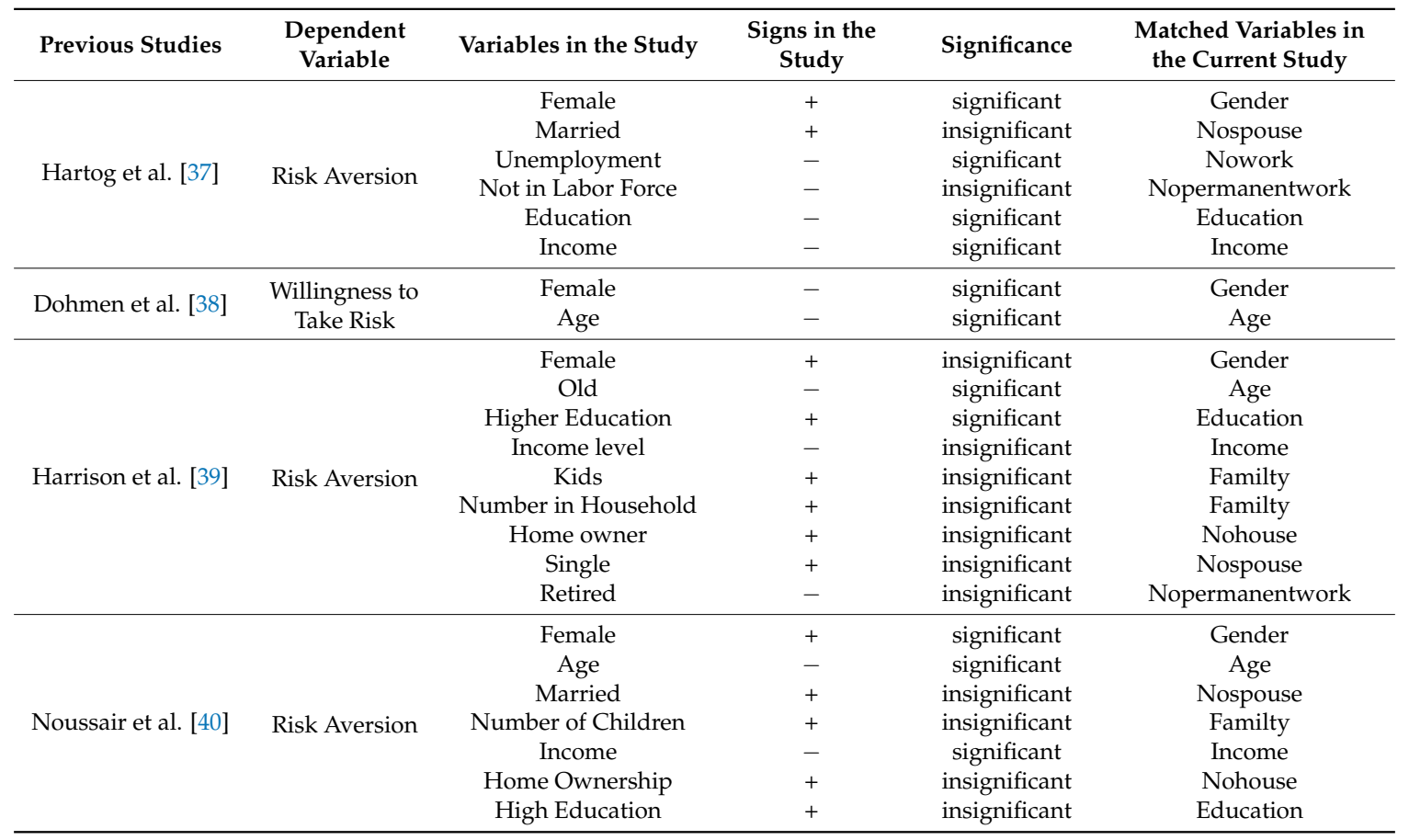


Given that financial education may help individuals to understand financial risk, we also included a variable indicating experience regarding financial education (Financeeducation) [41]. The definitions of the variables and expected signs in the model are shown in Table 2. As in Table 1, the variables' empirical signs in previous studies and their significance levels have not been fully consistent. Thus, we present the expected signs in our model for terms where the majority of previous studies have shown the same results. The signs in the table imply that males, old people, unemployed people and people without home ownership are more likely to accept higher interest rates.

Table 2. Definitions of Key Variables and Expected Signs in the Model.

\begin{tabular}{|c|c|c|}
\hline Variables & Descriptions & Expected Signs \\
\hline Interestintention & $\begin{array}{l}\text { The interest rate intended to pay to non-bank financial } \\
\text { institutions if he/she cannot get a loan from a commercial bank; }\end{array}$ & \\
\hline Gender & Gender. 1 for males and 0 otherwise; & $(+)$ \\
\hline Highrateloan & $\begin{array}{l}\text { The percentage of high interest (more than } 20 \% \text { ) debt in total } \\
\text { debt. A value is assigned between } 0(0 \%) \text { and } 5 \text { (more than } 50 \% \text { ), } \\
\text { increasing in steps of } 1 \text {; }\end{array}$ & \\
\hline Defaultexp & $\begin{array}{l}\text { Default experience. } 1 \text { if he/she has been in default by delaying } \\
\text { the payment more than } 3 \text { months for an amount over } 50,000 \\
\text { (approximately } 50 \$ \text { ); }\end{array}$ & \\
\hline Loantime & $\begin{array}{l}\text { Total time taken to search for loan information. The value is } \\
\text { assigned between } 1 \text { (less than } 1 \mathrm{~h} \text { ) and } 5 \text { (more than } 7 \mathrm{~h} \text { ), } \\
\text { increasing in steps of } 1 \text {; }\end{array}$ & \\
\hline Age & $\begin{array}{l}\text { Age. The value is assigned between } 1 \text { (for twenties) and } \\
5 \text { (higher than sixties), increasing in steps of } 1 \text {; }\end{array}$ & $(+)$ \\
\hline Family & The number of dependent family; & \\
\hline Nospouse & 1 if he/she has no spouse, otherwise 0 & \\
\hline Education & $\begin{array}{l}\text { Educational background. The value is assigned between } 1 \text { (for } \\
\text { elementary school graduation level or below) and } 6 \text { (over master } \\
\text { level), increasing in steps of } 1 \text {; }\end{array}$ & \\
\hline Financeeducation & The amount of finance education experience; & \\
\hline Nopermanentwork & 1 if he/she does not have permanent work position. 0 otherwise; & \\
\hline Nowork & 1 if he/she is unemployed. 0 otherwise; & $(+)$ \\
\hline Income & $\begin{array}{l}\text { The level of monthly income. The value is assigned between } \\
1 \text { (for elementary school graduation level or below) and } 8 \\
\text { (over master level), increasing in steps of } 1 \text {; }\end{array}$ & $(+)$ \\
\hline Nohouse & 1 if he/she does not have own house. Otherwise 0 ; & \\
\hline
\end{tabular}

In addition, we also investigated whether male participants are willing to pay higher interest rates when they are currently paying high interest rates. This investigation is important because if they intend to pay more interest in an economically challenging environment, they are more likely to become credit delinquents. Therefore, the following model was constructed by including the interaction variables, Gender and Highrateloan.

$$
\begin{aligned}
& \text { Interestintention } \\
& \qquad \begin{aligned}
= & b_{0}+b_{1} \text { Gender }+b_{2} \text { Gender } \times \text { Highrateloan }+b_{3} \text { Highrateloan } \\
+ & b_{4} \text { Defaultexp }+b_{5} \text { Loantime }+b_{6} \text { Age }+b_{7} \text { Family }+b_{8} \text { Nospouse } \\
+ & b_{9} \text { Education }+b_{10} \text { Financeeducation }+b_{11} \text { Nopermanentwork } \\
+ & b_{12} \text { Nowork }+b_{13} \text { Income }+b_{14} \text { Nohouse }+i e_{t}
\end{aligned}
\end{aligned}
$$




\section{Empirical Results}

\subsection{Descriptive Statistics}

Table 3 presents descriptive statistics and a comparison of our test variables between males and females. As our variables were measured by categorical values to reflect the multiple-choice answers in the survey, most variables are single digits. Among the 515 participants, the number of female participants was 408 , occupying about $80 \%$ of the sample. This implies that the majority of participants in the two financial accessibility plans are females. The mean value of Interestintention for females is significantly lower than that of males', supporting the hypothesis that males are more willing to pay higher interest rates. The difference indicates that males are less careful in regard to loan financial risk. In our sample, males had more dependent family members and more financial education experience. More importantly, the variables, Nopermanentwork and Nowork, were higher in female participants, implying that females tend to be excluded from stable jobs as well as having fewer jobs. The income level (Income) of males was shown to be higher than that of females. These patterns imply that males, relative to their female counterparts, tend to have more stable jobs and earn higher incomes. This tendency may imply a situation either where males are responsible for their family support or where females are disadvantaged in social activities in Korea. Even if this sample analysis provides useful insight about Korean society, the main interest of this study is not the diagnosis of this social situation. Thus, in this paper, we limit out study to the gender difference observed within low-income groups.

Table 3. Descriptive Statistics.

\begin{tabular}{|c|c|c|c|c|c|c|}
\hline \multicolumn{7}{|c|}{ Panel A: Sample Summary } \\
\hline & Num. of Obs. & Mean & SD & $25 \%$ & $50 \%$ (Median) & $75 \%$ \\
\hline Interestintention & 515 & 6.3911 & 3.7008 & 4.0000 & 5.5000 & 10.0000 \\
\hline Gender & 515 & 0.2078 & 0.4061 & 0.0000 & 0.0000 & 0.0000 \\
\hline Highrateloan & 515 & 0.4990 & 1.0954 & 0.0000 & 0.0000 & 0.0000 \\
\hline Defaultexp & 515 & 0.2136 & 0.4102 & 0.0000 & 0.0000 & 0.0000 \\
\hline Loantime & 515 & 3.2117 & 1.7399 & 2.0000 & 3.0000 & 5.0000 \\
\hline Age & 515 & 3.0621 & 0.7766 & 3.0000 & 3.0000 & 4.0000 \\
\hline Familty & 515 & 2.5107 & 1.1112 & 2.0000 & 2.0000 & 3.0000 \\
\hline Nospouse & 515 & 0.5262 & 0.4998 & 0.0000 & 1.0000 & 1.0000 \\
\hline Education & 515 & 3.2951 & 1.0298 & 3.0000 & 3.0000 & 4.0000 \\
\hline Financeeducation & 515 & 3.1126 & 1.5529 & 2.0000 & 3.0000 & 5.0000 \\
\hline Nopermanentwork & 515 & 0.7184 & 0.4502 & 0.0000 & 1.0000 & 1.0000 \\
\hline Nowork & 515 & 0.2039 & 0.4033 & 0.0000 & 0.0000 & 0.0000 \\
\hline Income & 515 & 2.3379 & 1.2089 & 1.0000 & 2.0000 & 3.0000 \\
\hline Nohouse & 515 & 0.9670 & 0.1788 & 1.0000 & 1.0000 & 1.0000 \\
\hline \multicolumn{7}{|c|}{ Panel B: Sample Comparison by Gender } \\
\hline & \multicolumn{2}{|c|}{ Gender $=0$ (Female) } & \multicolumn{2}{|c|}{ Gender $=1$ (Male) } & & \\
\hline & Num of Obs. & Mean (A) & Num of Obs. & Mean (B) & A-B & t-Stat \\
\hline Interestintention & 408 & 6.1480 & 107 & 7.3178 & -1.1697 & $-2.6905^{*}$ \\
\hline Highrateloan & 408 & 0.4828 & 107 & 0.5607 & -0.0779 & -0.0779 \\
\hline Defaultexp & 408 & 0.2230 & 107 & 0.1776 & 0.0455 & 0.0455 \\
\hline Loantime & 408 & 3.2525 & 107 & 3.0561 & 0.1964 & 0.1964 \\
\hline Age & 408 & 3.0368 & 107 & 3.1589 & -0.1221 & -0.1221 \\
\hline Familty & 408 & 2.4240 & 107 & 2.8411 & -0.4171 & $-3.3767 *$ \\
\hline Nospouse & 408 & 0.6054 & 107 & 0.2243 & 0.3811 & $8.0731^{*}$ \\
\hline Education & 408 & 3.3260 & 107 & 3.1776 & 0.1484 & 0.1484 \\
\hline Financeeducation & 408 & 3.0368 & 107 & 3.4019 & -0.3651 & $-2.1006^{*}$ \\
\hline Nopermanentwork & 408 & 0.7426 & 107 & 0.6262 & 0.1165 & $2.2509 *$ \\
\hline Nowork & 408 & 0.2279 & 107 & 0.1121 & 0.1158 & $3.1264 *$ \\
\hline Income & 408 & 2.2475 & 107 & 2.6822 & -0.4347 & $-3.3011 *$ \\
\hline Nohouse & 408 & 0.9706 & 107 & 0.9533 & 0.0173 & 0.0173 \\
\hline
\end{tabular}


Table 4 presents the correlation matrix for our key variables. These pairwise correlations reconfirm our findings shown in Table 3. Gender is significantly related to Interestintention, implying males are more likely to accept higher interest payments. Gender has a significant negative relationship with Nopermanentwork and Nowork. These results indicate that generally, males' job conditions are better than those of females'. Income and Gender have a significant association, showing that males' income levels are higher. The correlation matrix also shows the determinants of Interestintention. If an individual is currently paying high interest rates (Highrateloan), he/she is more likely to accept higher interest rates. Default experience (Defaultexp) seems to make the individual accept higher interest rates. In addition, individuals with default experience (Defaultexp) were currently paying high interest rates (Highrateloan). These relationships imply that an individual's financial difficulty may persist because individuals in financial difficulty may accept even higher interest rates. Other than these relationships, the table also shows the effects of labor conditions on income. If an individual does not have a permanent employment position (Nopermanentwork), his/her income (Income) is low. This relationship shows the importance of job security to support economic welfare.

In the table, the pairwise correlation coefficients are generally between -0.30 and 0.30 . Thus, we expect low multicollinearity. We statistically checked the multicollinearity with the VIF (Variance Inflation Factor) of each coefficient in the regression model. The multicollinearity problem is determined to be small if the VIF is close to 1 . In contrast, it is regarded as serious if it is greater than 5. In our study, the VIF values remained between 1.0 to 1.9. Thus, multicollinearity among variables seems not to be serious. Even if the correlation matrix itself provides useful implications, careful interpretation is needed because in the correlation matrix, the other variables are not controlled for.

\subsection{Regression Results}

Table 5 presents the empirical results regarding the association between gender and the intention to pay high interest rates. The coefficient, Gender, is significantly positive $(1.138, p$-value $<0.05)$ in the first column, implying that males are more likely to pay higher interest rates than females when they cannot get a bank loan. The signs of the other variables are generally consistent with our hypotheses-the higher interest rates they are currently paying, the higher the interest rates they are willing to pay, as indicated by the coefficient, Highrateloan $(0.530, p$-value $<0.01)$. The significance of Defaultexp $(0.952, p$-value $<0.05)$ implies that default experience is correlated with the acceptance of higher interest rates. In addition, the coefficients Age and Income have positive signs, consistent with our expectations. While the coefficient of Nowork is negative, it is insignificant. Thus, the results generally support our expectations.

We examined whether males are more likely to pay high interest rates if they are currently paying high interest rates. If so, this implies that the financial conditions of the male participants who are experiencing financial difficulties may deteriorate as they are willing to pay even higher interest rates. Column 2 in Table 5 shows the results. The significantly positive sign for Highrateloan $\times$ Gender $(1.102, p$-value $<0.05)$ shows that males are willing to pay more interest when their current financial conditions are not friendly. In contrast, the insignificant sign for Highrateloan implies that females' intention to pay high interest is not strongly associated with their current financial conditions. These results imply that the males under financial distress are more likely to become credit delinquents by paying higher interest rates in future. 
Table 4. Correlation Matrix.

\begin{tabular}{|c|c|c|c|c|c|c|c|c|c|c|c|c|c|}
\hline & Interestintention & Gender & Highrateloan & Defaultexp & Loantime & Age & Familty & Nospouse & Education & Financeeducation & Nopermanentwork & Nowork & Income \\
\hline Gender & $0.1284 *$ & & & & & & & & & & & & \\
\hline Highrateloan & $0.1777^{*}$ & 0.0289 & & & & & & & & & & & \\
\hline Defaultexp & $0.0995 *$ & -0.045 & $0.1650 *$ & & & & & & & & & & \\
\hline Loantime & -0.0435 & -0.0458 & 0.0547 & 0.0783 & & & & & & & & & \\
\hline Age & -0.0221 & 0.0639 & -0.0228 & 0.0621 & -0.017 & & & & & & & & \\
\hline Familty & 0.0508 & 0.1524 * & -0.0372 & -0.0562 & 0.0597 & -0.1856 * & & & & & & & \\
\hline Nospouse & -0.022 & -0.3097 * & 0.0205 & 0.0201 & 0.0283 & 0.066 & $-0.5899 *$ & & & & & & \\
\hline Education & -0.0345 & -0.0585 & -0.0791 & -0.0206 & -0.0143 & -0.2784 * & 0.1757 * & -0.0793 & & & & & \\
\hline Financeeducation & -0.0408 & 0.0955 * & 0.0024 & 0.0324 & 0.0394 & $0.2168^{*}$ & -0.0582 & -0.0113 & -0.0439 & & & & \\
\hline Nopermanentwork & -0.0453 & -0.1051 * & 0.0211 & $0.1577^{*}$ & -0.0182 & 0.0835 & -0.0115 & -0.0493 & -0.068 & -0.1048 * & & & \\
\hline Nowork & -0.0349 & -0.1166 * & -0.0062 & 0.0067 & 0.041 & -0.1399 * & $0.0928 *$ & $-0.1086^{*}$ & 0.0469 & $-0.1610^{*}$ & $0.3168 *$ & & \\
\hline Income & $0.1380 *$ & 0.1460 * & -0.01 & -0.1105 * & 0.0029 & -0.2234 * & 0.3681 * & $-0.4107^{*}$ & 0.2620 * & 0.0232 & $-0.1823 *$ & -0.0378 & \\
\hline Nohouse & 0.0372 & -0.0393 & 0.0147 & $0.0963 *$ & -0.065 & 0.0568 & -0.1010 * & $0.1294 *$ & 0.0002 & 0.0344 & 0.0052 & -0.0144 & -0.0653 \\
\hline
\end{tabular}

Notes: This table shows the pairwise correlations among the key variables. * Denotes significance at the $5 \%$ level or lower. See Table 1 for variable definitions. 
Table 5. Regression Results.

\begin{tabular}{|c|c|c|}
\hline & Interestintention & Interestintention \\
\hline \multirow[t]{2}{*}{ Gender } & $1.138 * *$ & 0.523 \\
\hline & $(0.449)$ & $(0.457)$ \\
\hline \multirow[t]{2}{*}{ Highrateloan } & $0.530^{* * *}$ & 0.320 \\
\hline & $(0.200)$ & $(0.231)$ \\
\hline \multirow[t]{2}{*}{ Highrateloan $\times$ gender } & & $1.102^{* *}$ \\
\hline & & $(0.442)$ \\
\hline \multirow[t]{2}{*}{ Defaultexp } & $0.952 * *$ & $0.942 * *$ \\
\hline & $(0.465)$ & $(0.462)$ \\
\hline \multirow[t]{2}{*}{ Loantime } & -0.124 & $-0.137^{*}$ \\
\hline & $(0.084)$ & $(0.082)$ \\
\hline \multirow[t]{2}{*}{ Age } & 0.018 & -0.016 \\
\hline & $(0.249)$ & $(0.249)$ \\
\hline \multirow[t]{2}{*}{ Familty } & 0.192 & 0.206 \\
\hline & $(0.189)$ & $(0.186)$ \\
\hline \multirow{2}{*}{ Nospouse } & 0.784 * & 0.745 \\
\hline & $(0.464)$ & $(0.462)$ \\
\hline \multirow[t]{2}{*}{ Education } & -0.228 & -0.233 \\
\hline & $(0.158)$ & $(0.157)$ \\
\hline \multirow[t]{2}{*}{ Financeeducation } & -0.146 & -0.145 \\
\hline & $(0.113)$ & $(0.113)$ \\
\hline \multirow{2}{*}{ Nopermanentwork } & -0.217 & -0.175 \\
\hline & $(0.387)$ & $(0.384)$ \\
\hline \multirow[t]{2}{*}{ Nowork } & -0.024 & -0.063 \\
\hline & $(0.418)$ & $(0.418)$ \\
\hline \multirow[t]{2}{*}{ Income } & $0.525^{* * *}$ & $0.504^{* * *}$ \\
\hline & $(0.163)$ & $(0.159)$ \\
\hline \multirow[t]{2}{*}{ Nohouse } & 0.645 & 0.490 \\
\hline & $(0.583)$ & $(0.610)$ \\
\hline \multirow[t]{2}{*}{ Constant } & $4.653^{* * *}$ & $5.082 * * *$ \\
\hline & $(1.357)$ & $(1.348)$ \\
\hline N. of Obs. & 515 & 515 \\
\hline adj. R-sq & 0.065 & 0.079 \\
\hline F-statistic & $F(13,501)=3.19$ & $F(14,500)=3.65$ \\
\hline Prob $>$ F & 0.0001 & 0.0000 \\
\hline
\end{tabular}

Note: $* * *, * *, *$ indicate statistical significance at the $1 \%, 5 \%$, and $10 \%$ levels for two-tailed tests, respectively. Standard errors are presented in the parentheses.

We also investigated the gender difference by dividing our sample based on gender. The results are shown in Table 6 . The first column of Table 6 shows the main regression results for the female sample. Consistent with the results in Table 5, the coefficient of Highrateloan does not show significance, implying that females are less likely to accept higher interest rates, even if their current financial costs are high. However, as shown in the second column, males have different perceptions about interest risk compared to females. The coefficient of Highrateloan is significantly positive, indicating that males are more likely to accept high interest rates when their current interest costs are high. Thus, it may be difficult for males under high financial burden in low-income groups to escape the group because their financial burden may be even higher. This difference may illustrate why the financial accessibility policy can be less effective for males.

In addition, we divided our sample into two based on Highrateloan and found that the coefficient of Gender was significant only within the high Highrateloan subsample (untabulated). These additional results also support the hypothesis that males under financial distress are more likely to pay higher interest rates in the future. 
Table 6. Regression Results within Divided Samples.

\begin{tabular}{|c|c|c|}
\hline & Gender $=0$ (Female) & Gender $=1$ (Male) \\
\hline & Interestintention & Interestintention \\
\hline \multirow[t]{2}{*}{ Highrateloan } & 0.337 & $1.316^{* * *}$ \\
\hline & $(0.232)$ & $(0.355)$ \\
\hline \multirow[t]{2}{*}{ Defaultexp } & 0.581 & $2.626^{* *}$ \\
\hline & $(0.497)$ & (1.133) \\
\hline \multirow[t]{2}{*}{ Loantime } & $-0.158 *$ & 0.042 \\
\hline & $(0.090)$ & $(0.214)$ \\
\hline \multirow[t]{2}{*}{ Age } & -0.055 & 0.265 \\
\hline & $(0.261)$ & $(0.595)$ \\
\hline \multirow[t]{2}{*}{ Familty } & -0.056 & $1.032^{* * *}$ \\
\hline & $(0.217)$ & $(0.375)$ \\
\hline \multirow{2}{*}{ Nospouse } & 0.283 & $2.458^{* *}$ \\
\hline & $(0.519)$ & $(1.031)$ \\
\hline \multirow[t]{2}{*}{ Education } & -0.235 & 0.165 \\
\hline & $(0.180)$ & $(0.396)$ \\
\hline \multirow[t]{2}{*}{ Financeeducation } & -0.176 & -0.004 \\
\hline & $(0.126)$ & $(0.236)$ \\
\hline \multirow{2}{*}{ Nopermanentwork } & -0.082 & 0.180 \\
\hline & $(0.445)$ & $(0.889)$ \\
\hline \multirow[t]{2}{*}{ Nowork } & -0.386 & 0.950 \\
\hline & $(0.450)$ & (1.316) \\
\hline \multirow[t]{2}{*}{ Income } & $0.569^{* * *}$ & 0.195 \\
\hline & $(0.189)$ & $(0.315)$ \\
\hline \multirow[t]{2}{*}{ Nohouse } & 0.834 & -0.393 \\
\hline & $(0.775)$ & $(0.985)$ \\
\hline \multirow[t]{2}{*}{ Constant } & $5.876^{* * *}$ & 0.785 \\
\hline & $(1.528)$ & (3.157) \\
\hline $\mathrm{N}$ & 408 & 107 \\
\hline adj. R-sq & 0.033 & 0.188 \\
\hline F-statistic & $F(12,395)=1.95$ & $\mathrm{~F}(12,94)=4.11$ \\
\hline Prob $>$ F & 0.0276 & 0.0000 \\
\hline
\end{tabular}

Note: ${ }^{* * *}, * *, *$ indicate statistical significance at the $1 \%, 5 \%$, and $10 \%$ levels for two-tailed tests, respectively. Standard errors are presented in the parentheses.

\subsection{Additional Analysis}

Our analysis may suffer from an endogeneity issue because Gender (male $=1$ ) may reflect unobserved factors that may affect the intention to pay higher interest rates. For example, males are more likely to accept higher financial costs if their economic conditions tend to be better than females or if they need to support their family immediately. Under these situations, the difference between males and females may merely reflect males' different socioeconomic conditions, rather than gender difference. To address this concern, we adopted propensity score matching (hereafter, PSM matching) which has been introduced in previous studies [42,43]. PSM matching helps to compare male samples to females with similar characteristics by estimating their propensity score. For estimation of the propensity score, we used the probit model by regressing Gender against the control variables of our main model. Then, we made a matched sample. This procedure minimizes the differences between male and female samples, except Gender itself.

Table 7 compares the differences between males and females. The numbers of observations are the same in both samples due to the matching process. The differences between males and females disappear except Interestintention, showing that our matching procedure was well performed. The significant difference observed for Interestintention shows that gender difference still survives even in the matched sample, implying that males' willingness to pay high interest rate is not due to a difference in socioeconomic conditions.

In Table 8, we replicate our main results with the matched sample. The coefficient, Gender is still significantly positive $(1.023, p$-value $<0.05)$ in the first column. In the second column, the 
significant positive sign of Highrateloan $\times$ Gender $(1.736, p$-value $<0.01)$ is also consistent with our prior result. These additional results imply that our main results do not reflect males' different socioeconomic conditions.

Table 7. Descriptive Statistics for the Matched Sample.

\begin{tabular}{ccccccc}
\hline & \multicolumn{2}{c}{ Gender = 0 (Female) } & \multicolumn{2}{c}{ Gender = 1 (Male) } & & \\
\cline { 2 - 7 } & Num of Obs. & Mean (A) & Num of Obs. & Mean (B) & A-B & t-Stat \\
\hline Interestintention & 107 & 6.2495 & 107 & 7.3178 & -1.1068 & $-2.0359 *$ \\
Highrateloan & 107 & 0.5421 & 107 & 0.5607 & -0.0187 & -0.1218 \\
Defaultexp & 107 & 0.1495 & 107 & 0.1776 & -0.0280 & -0.5523 \\
Loantime & 107 & 3.0187 & 107 & 3.0561 & -0.0374 & -0.1589 \\
Age & 107 & 3.1122 & 107 & 3.1589 & -0.0467 & -0.4192 \\
Familty & 107 & 2.8879 & 107 & 2.8411 & 0.0467 & 0.3035 \\
Nospouse & 107 & 0.2150 & 107 & 0.2243 & -0.0093 & -0.1644 \\
Education & 107 & 3.1028 & 107 & 3.1776 & -0.0748 & -0.5501 \\
Financeeducation & 107 & 3.2897 & 107 & 3.4019 & -0.1121 & -0.5249 \\
Nopermanentwork & 107 & 0.6916 & 107 & 0.6262 & 0.0654 & 1.0070 \\
Nowork & 107 & 0.1028 & 107 & 0.1121 & -0.0093 & -0.2197 \\
Income & 107 & 2.7196 & 107 & 2.6822 & 0.0374 & 0.2126 \\
Nohouse & 107 & 0.9439 & 107 & 0.9533 & -0.0093 & -0.3082 \\
\hline
\end{tabular}

Notes: In the last column, ${ }^{*}$ denotes significance at the $5 \%$ level or lower.

Table 8. Regression Results.

\begin{tabular}{|c|c|c|}
\hline & Interestintention & Interestintention \\
\hline \multirow[t]{2}{*}{ Gender } & 1.023 ** & 0.082 \\
\hline & $(0.502)$ & $(0.491)$ \\
\hline \multirow[t]{2}{*}{ Highrateloan } & 0.337 & -0.424 \\
\hline & $(0.258)$ & $(0.358)$ \\
\hline \multirow[t]{2}{*}{ Highrateloan $\times$ gender } & & $1.736^{* * *}$ \\
\hline & & $(0.507)$ \\
\hline \multirow[t]{2}{*}{ Defaultexp } & $2.682 * * *$ & $2.624^{* * *}$ \\
\hline & $(0.839)$ & $(0.810)$ \\
\hline \multirow[t]{2}{*}{ Loantime } & -0.036 & -0.046 \\
\hline & $(0.136)$ & $(0.127)$ \\
\hline \multirow[t]{2}{*}{ Age } & 0.328 & 0.256 \\
\hline & (0.437) & (0.428) \\
\hline \multirow[t]{2}{*}{ Familty } & $0.765^{* * *}$ & $0.803^{* * *}$ \\
\hline & $(0.264)$ & $(0.257)$ \\
\hline \multirow[t]{2}{*}{ Nospouse } & $1.889^{* *}$ & $1.807^{* *}$ \\
\hline & (0.735) & $(0.710)$ \\
\hline \multirow[t]{2}{*}{ Education } & -0.062 & -0.093 \\
\hline & $(0.283)$ & $(0.273)$ \\
\hline \multirow[t]{2}{*}{ Financeeducation } & -0.106 & -0.089 \\
\hline & $(0.175)$ & $(0.172)$ \\
\hline \multirow{2}{*}{ Nopermanentwork } & 0.193 & 0.339 \\
\hline & $(0.589)$ & $(0.585)$ \\
\hline \multirow[t]{2}{*}{ Nowork } & 0.737 & 0.800 \\
\hline & $(0.826)$ & $(0.801)$ \\
\hline \multirow{2}{*}{ Income } & 0.394 * & 0.375 * \\
\hline & $(0.227)$ & $(0.209)$ \\
\hline \multirow[t]{2}{*}{ Nohouse } & 0.562 & 0.337 \\
\hline & $(0.686)$ & $(0.771)$ \\
\hline \multirow[t]{2}{*}{ Constant } & 0.864 & 1.651 \\
\hline & $(2.232)$ & $(2.144)$ \\
\hline N. of Obs. & 214 & 214 \\
\hline adj. R-sq & 0.104 & 0.166 \\
\hline F-statistic & $F(13,200)=3.30$ & $\mathrm{~F}(14,199)=5.10$ \\
\hline Prob $>$ F & 0.0001 & 0.0000 \\
\hline
\end{tabular}

Note: ${ }^{* * *}, * *, *$ indicate statistical significance at the $1 \%, 5 \%$, and $10 \%$ levels for two-tailed tests, respectively. Standard errors are presented in the parentheses. 


\section{Discussion and Conclusions}

A decrease in income inequality is crucial factor for society to allow sustainable economic growth. Providing sufficient financial accessibility to low-income individuals is considered an effective way to decrease income inequality. However, attitudes towards financial risk within low-income groups have not been investigated. This study addresses this issue. We employed gender as our main interest variable because even though previous studies have investigated gender differences in risk-taking behavior, current public policy on financial accessibility tends not to reflect the gender difference factor.

Despite its contributions, this study has the following limitations. First, our study used an empirical analysis of gender difference in risk attitude within low-income groups. Thus, it does not provide the causes of differences shown. Second, as we have basically used raw data from multiple-choice type questions, we converted most variables into categorical values to reflect the multiple-choice answers of individuals. Thus, this study is not free from the potential information loss due to the nature of the data style. Third, even though we found that males are more likely to accept higher interest rate payments, it is doubtful whether the result really leads to a higher interest burden in males. At this stage, we cannot make definitive conclusions due to data scarcity.

Our findings, however, shed light on how we can reach sustainable financial health in socially and economically under-privileged communities by investigating gender differences in risk-taking behaviors and their motivations. First of all, we found that males are more willing to pay higher interest rates compared to females. In addition, males' high willingness to pay high interest rates becomes stronger when their current financial costs are high. These results indicate that males are relatively ignorant of, or disregard, the risks that high interest rates can bring. In addition, these results also imply that the intention to pay higher interest rates may hinder males from escaping their low-income status by increasing their financial burden.

The implications of the results of this study are as follows: First, this study shows that there needs to be a focus on low-income males to help them avoid excessive financial burden. Second, this study extends prior literature about gender differences in risk-taking to differences in loan behavior. Third, this result implies that males may accumulate wealth because of their risk attitudes; however, for that very reason, they may have difficulty escaping from their low-income status. In summary, this study provides a useful milestone regarding what to supplement in financial accessibility plans that aim to decrease income inequality and achieve sustainable economic growth.

Our study may introduce research opportunities in related areas. First, our study did not present a concrete improvement direction for current financial accessibility plans. Thus, a promising future research project may be preparing an alternative financial accessibility plan that reflects the gender difference from a public policy perspective. Second, our study examined the gender differences between interest payment intentions in general for low-income people. Extending the results to various types of loans (e.g., consumption vs. mortgages) may present unexplored, meaningful implications.

Acknowledgments: This work was supported by the Hongik University new faculty research support fund.

Author Contributions: Eunmi Kim collected the survey data and summarized related prior literature; Sejoong Lee performed empirical analysis and wrote the major parts of the paper; Joonwhan David Lee supplemented several parts of the paper and refined the whole.

Conflicts of Interest: The authors declare no conflict of interest.

\section{References}

1. Cingano, F. Trends in Income Inequality and its Impact on Economic Growth. In OECD Social, Employment and Migration Working Papers; OECD: Paris, France, 2014.

2. Ostry, J.; Berg, A.; Tsangarides, C. Redistribution, Inequality, and Growth. In IMF Staff Discusstion Note; IMF: Washington, DC, USA, 2014.

3. World Economic Forum. The Financial Development Report; World Economic Forum: Cologny, Switzerland, 2012. 
4. Greene, W.; Rhine, S.; Toussaint-Comeau, M. The Importance of Check-Cashing Businesses to the Unbanked: Racial/Ethnic Differences. Rev. Econ. Stat. 2006, 88, 146-157. [CrossRef]

5. Bruhn, M.; Love, I. Gender differences in the impact of banking services: Evidence from Mexico. Small Bus. Econ. 2011, 37, 493. [CrossRef]

6. United Nations. The Road to Dignity by 2030: Ending Poverty, Transforming All Lives and Protecting the Planet; United Nations: New York, NY, USA, 2014.

7. World Bank. Finance for All? Policies and Pitfalls in Expanding Access; World Bank: Washington, DC, USA, 2008.

8. Dwyer, P.D.; Gilkeson, J.H.; List, J.A. Gender differences in revealed risk taking: Evidence from mutual fund investors. Econ. Lett. 2002, 76, 151-158. [CrossRef]

9. Fisher, P.J.; Yao, R. Gender differences in financial risk tolerance. J. Econ. Psychol. 2017, 61, 191-202. [CrossRef]

10. Charness, G.; Gneezy, U. Strong Evidence for Gender Differences in Risk Taking. J. Econ. Behav. Organ. 2012, 83, 50-58. [CrossRef]

11. Almenberg, J.; Dreber, A. Gender, stock market participation and financial literacy. Econ. Lett. 2015, 137, 140-142. [CrossRef]

12. Caspar, R. Does female board representation influence firm performance? The Danish evidence. Corp. Gov. Int. Rev. 2007, 15, 404-413. [CrossRef]

13. Marinova, J.; Plantenga, J.; Remery, C. Gender diversity and firm performance: Evidence from Dutch and Danish boardrooms. Int. J. Hum. Resour. Manag. 2016, 27, 1777-1790. [CrossRef]

14. Shrader, C.B.; Blackburn, V.B.; Iles, P. Women In Management And Firm Financial Performance: An Exploratory Study. J. Manag. Issues 1997, 9, 355-372.

15. Kim, D.-Y.; Lehto, X.; Morrison, A.M. Gender differences in online travel information search: Implications for marketing Communications on the Internet. Tour. Manag. 2007, 28, 423-433. [CrossRef]

16. Buser, T.; Niederle, M.; Oosterbeek, H. Gender, Competitiveness and Career Choices. Q. J. Econ. $2012,129$. [CrossRef]

17. Han, W.; Hellmann, A.; Lu, M. The impact of gender difference on the interpretation of uncertainty expressions. Asian Rev. Account. 2016, 24. [CrossRef]

18. Dreber, A.; Johannesson, M. Gender Differences in Deception. Econ. Lett. 2008, 99, 197-199. [CrossRef]

19. Lane, J.C. Ethics of Business Students: Some Marketing Perspectives. J. Bus. Ethics 1995, 14, 571-580. [CrossRef]

20. Franke, G.R.; Crown, D.; Spake, D. Gender differences in ethical perceptions of business practices: A social role theory perspective. J. Appl. Psychol. 1998, 82, 920-934. [CrossRef]

21. Anthony, D.; Horne, C. Gender and Cooperation: Explaining Loan Repayment in Micro-Credit Groups. Soc. Psychol. Q. 2003, 66, 293-302. [CrossRef]

22. Hyun, E.; Yang, D.; Jung, H.; Hong, K. Women on Boards and Corporate Social Responsibility. Sustainability 2016, 8, 300. [CrossRef]

23. E-Vahdati, S.; Zulkifli, N.; Zakaria, Z. A Moderated Mediation Model for Board Diversity and Corporate Performance in ASEAN Countries. Sustainability 2018, 10, 556. [CrossRef]

24. Lin, X.; Featherman, M.; Sarker, S. Understanding Factors Affecting Users' Social Networking Site Continuance: A Gender Difference Perspective. Inf. Manag. 2016, 54, 383-395. [CrossRef]

25. Roberts, J.; Hodgson, R.; Dolan, P. "It's driving her mad": Gender differences in the effects of commuting on psychological health. J. Health Econ. 2011, 30, 1064-1076. [CrossRef] [PubMed]

26. Buser, T.; Dreber, A.; Mollerstrom, J. The impact of stress on tournament entry. Exp. Econ. 2017, 20, 506-530. [CrossRef] [PubMed]

27. Kim, B.; Jeong, J. Dynamics of adolescents' life satisfaction and effect of class rank percentile: Evidence from Korean panel data. J. Econ. Psychol. 2017, 59, 8-28. [CrossRef]

28. Lundeberg, M.; Fox, P.W.; Punćcohaŕ, J. Highly Confident but Wrong: Gender Differences and Similarities in Confidence Judgments. J. Educ. Psychol. 1994, 86, 114-121. [CrossRef]

29. Byrnes, J.; Miller, D.; Schafer, W.D. Gender Differences in Risk Taking: A Meta-Analysis. Psychol. Bull. 1999, 125, 367-383. [CrossRef]

30. Tutek, H.; Aydoğan, B.; Tunc, G.; Vardar, G. The impact of gender differences on financial risk perceptions. Iktis. Islet. Finans 2010, 25, 47-70.

31. Croson, R.; Gneezy, U. Gender Differences in Preferences. J. Econ. Lit. 2009, 47, 448-474. [CrossRef] 
32. Powell, M.; Ansic, D. Gender Differences in Risk Behavior in Financial Decision-Making: An Experimental Analysis. J. Econ. Psychol. 1997, 18, 605-628. [CrossRef]

33. Wang, A. Interplay of Investors' Financial Knowledge and Risk Taking. J. Behav. Financ. 2009, 10, $204-213$. [CrossRef]

34. Jianakoplos, N.; Bernasek, A. Are Women More Risk Averse? Econ. Inq. 1998, 36, 620-630. [CrossRef]

35. Yun, K.; Man, S.S.; Hee Young, S.Y. Study on Credit Risk Factors of Policy Financing Using Survival Analysis TT. J. Korean Reg. Econ. 2017, 37, 27-40.

36. Seoul Welfare Foundation. The Survey on the Needs and Use of Financial Services of Financially Excluded People; Seoul Welfare Foundation: Seoul, Korea, 2014.

37. Hartog, J.; Ferrer-i-Carbonell, A.; Jonker, N. Linking Measured Risk Aversion to Individual Characteristics. Kyklos 2002, 55, 3-26. [CrossRef]

38. Dohmen, T.; Falk, A.; Huffman, D.; Sunde, U.; Schupp, J.; Wagner, G.G. Individual Risk Attitudes: Measurement, Determinants, and Behavioral Consequences. J. Eur. Econ. Assoc. 2011, 9, 522-550. [CrossRef]

39. Harrison, G.W.; Lau, M.I.; Rutström, E.E. Estimating Risk Attitudes in Denmark: A Field Experiment*. Scand. J. Econ. 2007, 109, 341-368. [CrossRef]

40. Noussair, C.N.; Trautmann, S.T.; van de Kuilen, G. Higher Order Risk Attitudes, Demographics, and Financial Decisions. Rev. Econ. Stud. 2014, 81, 325-355. [CrossRef]

41. French, D.; McKillop, D. Financial literacy and over-indebtedness in low-income households. Int. Rev. Financ. Anal. 2016, 48, 1-11. [CrossRef]

42. Rosenbaum, P.R.; Rubin, D.B. The Central Role of the Propensity Score in Observational Studies for Causal Effects. Biometrika 1983, 70, 41-55. [CrossRef]

43. Ignacio, G.J.; Alberto, M.J. Commuting Time and Household Responsibilities: Evidence Using Propensity Score Matching. J. Reg. Sci. 2015, 56, 332-359. [CrossRef]

(C) 2018 by the authors. Licensee MDPI, Basel, Switzerland. This article is an open access article distributed under the terms and conditions of the Creative Commons Attribution (CC BY) license (http:/ / creativecommons.org/licenses/by/4.0/). 